\title{
The Influence of Design Team Attributes on Green Design Performance of Building Projects
}

\author{
Mohamed S. Elforgani (Corresponding author) \\ Department of built Environment, Faculty of Architecture Planning and Survey \\ Universiti Teknologi MARA \\ C-17-01- Ampang Prima Condo- Bdr Baru Ampang - Ampang - 68000-Malysia \\ Tel: 60-16-206-0946_E-mail: forjani69@yahoo.com
}

Ismail Bin Rahmat

Department of built Environment

Faculty of Architecture Planning and Survey, Universiti Teknologi MARA Tel: 60-10-225-2204Ｅ-mail: ismail046@salam.uitm.edu.my

Received: April 13, 2012 Accepted: April 18, 2012 Online Published: April 26, 2012 doi:10.5296/emsd.v1i1.1623ＵRL: http://dx.doi.org/10.5296/emsd.v1i1.1623 


\title{
Macrothink

\begin{abstract}
The design phase is the most important phase in determining the green performance of building projects. The performance of the design team is crucial. The growing importance of sustainability globally necessitates the inclusion of green criteria in the design team selection process. Therefore, a competent design teams is required to have a range of attributes as the basis for design decisions. The propose of this study to identify current green design performance level of design teams of building projects and establish key design attributes influencing green design performance. To achieve mentioned aim a questionnaire survey was conducted to collect dada required. A sample of 274 respondents has been covered under the study, including architects and engineers practicing design and consultancy building sectors. Prior to analysis of data WINSTEPS software were used to determine validity and reliability of date. Descriptive analysis data includes quantitative and qualitative. In general, design team attributes were moderate (3.32). The general design team attributes were high such experience (3.81), communication (3.43) and leadership effectiveness (3.48). However, green attributes of design team were moderate such as green knowledge (2.98), green skills (3.13) and green initiatives (2.84).The result indicates that most design teams have inadequate knowledge and skills to produce high green design performance of building projects. Therefore, to overcome green design complexity, careful selecting design team members and more education and training courses on green building are required to deal with green design requirements.
\end{abstract}

Keywords: Construction Industry, Green Design Performance, Design Team Attributes 


\section{Introduction}

The design phase is the most important phase in determining the green performance of construction projects because more than half of construction mistakes were caused by design insufficiency (Alwaera and Croomeb, 2010; Graham, 2003; Lukumon and Thamb, 2007).

The design process of building projects involves individuals from different background and different orientations and values (Mathieu et al., 2008). These individuals do not automatically work together. For them to work effectively, they need to be coordinated and has a set of clear rules and rewards (Cohen and Bailey, 1997) and (Vardi and Waits, 2004).

Work arrangements that involve teams are frequently better organized and more effective than individual work (Hoegl and Gemuenden, 2001; Loughry et al., 2005). Peeters et al. (2006), Keyton and Beck (2008) stated that arranging work into teams that have a mixture of complementary skills, knowledge, attitudes and other characteristics is more effective that if the members work individually.Therefore, teamwork has become indispensable in many organizations. (Mohammed and Ringseis, 2001; Salas et al., 1995).

Klein and Kozlowski (2008) noted the increasing trend of using teamwork to improve both team and individual performance. However, (Sonnentag and Frese, 2002) argued that since teams are composed of individuals, it is impractical to improve team performance and team processes without considering the performance of individuals because teams are consisting individuals.

From the literatures mentioned above, it could be concluded that in order to perform well, be it in terms of time, cost or green requirements, having an effective design team is vital. However, literature review revealed that not much research being conducted on identifying the attributes of the design teams in building projects. There is no research in Malaysia to establish to what extent the attributes of the design teams influence the green design performance of building projects. Therefore, the main objectives of this study are:

- To identify attributes of the design teams during the design process of building projects

- To establish the relationship between the attributes of the design team and the green design performance

\section{Literature Review on the Effective Design Team Attributes}

Since the performance of the design team is crucial, the selection of the design team members be assessed on the key criteria that ensure the design team performance Jayasel (2006). Many studies have focused on identifying key team attributes that lead to performance enhancement. Rajagopal and Rajagopal (2006) identified that the basic attributes of an effective team comprise of clarity of goals, clarity of roles, censoriousness, motivation as well as a collaborative and commitment attitude. While and Driskell et al.(2006) discussed the attributes of team strengths. The four attributes include high personal satisfaction when performing tasks, continuous learning, achieving results with exceptional and passionate interest and in particular and the task.

Mohan and Anvuur (2008) found that the key criteria for selecting a green team for PPP projects where team commitment, receptivity, team loyalty, attention and shared 
decision-making innovativeness. Yean (2002) for instance, identified 24 attributes design team members, specifically the architects and engineers that have an influence to the team performance. The attributes were categorized into hard and soft attributes. The hard attributes consist of cognitive ability, task proficiency and job experience and job knowledge. While, soft attributes consist of conscientiousness, social skills, initiative, commitment and controllability. Jayasel (2006), on the other hand, gathered a list of criteria used for the performance evaluation of construction professionals and categorized them into three main categories, which are general performance in different project stages, client satisfaction and job performance.

The growing importance of sustainability globally necessitates the inclusion of green criteria in the design team selection process (Baars and Gerarde, 2006; Graham, 2003; Kumaraswamy and Anvuur, 2008). Therefore, a competent design teams is required to have a good understanding of environmental issues and must be capable of understanding the environmental impacts of selected materials as related to energy, indoor environmental issues, water consumption and other resources (Graham, 2003). Moreover, design teams require a range of competences such as skills of environmental assessments, initiatives and environmental background as the basis for design decisions (Koukkari et al., 2005). In this context, Kerr (2008), recommended a careful selection process which ensures that all design team members have demonstrated competency to achieve low energy buildings with acknowledged environmental qualifications. High-performance buildings require the integration of environmental concerns from their initial stages.

In practice, assembling a green design teams from scratch is extremely hard.Teamwork is difficult to achieve because each building project is different and requires different team members requirements (Chi and Chen, 2009). Project objectives can only be achieved through optimal composition of individuals' attributes and attitudes (Peeters et al., 2006).

A number of studies refer team composition to the attributes of the team members who structure the team as well as how those attributes are distributed within the team (Jackson et al., 2003; Kozlowski and Ilgen, 2006). Drawing from literature, 21 design team attributes were identified as crucial for high green design performance. These attributes were classified into two groups, namely, general attributes and green attributes. The general attributes are essential for design team in order to produce high quality design, whereas green attributes selected are essential for design team members to produce green design. General and green design team attributes selected are explained as follow:

\subsection{General Design Team Attributes}

\subsubsection{Design team experience}

According to Mac Cormack et al. (2001) discovered that teams with a great experience base were performing better. These findings were supported by Krishnan (1998) who also found that highly skilled teams with larger experience levels had fewer defects. Sahil (2008) studied factors influencing the performance of construction consultancy firms. He found one of the most significant factors is poor previous work experience. Lee and Egbu (2006) recommended that multiple skills and a variety of relevant experience with various competent knowledge features of building design is needed. 


\subsubsection{Effective design team management}

Recognizing how to make teams effective is an important factor in enhancing the performance of an organization, (Strubler and York, 2007). Many researchers Hyatt and Ruddy (1997), Jordan and Armenakis (2002), Carpenter (2002), LePine (2003), Mohamed (2003) and Loughry et al. (2005) have investigated one or a few variables that are associated with team effectiveness that have been documented in literature about teams, these include factors of the organizational setting that support team effectiveness.

In this context, Humphrey et al. (2009) noted that performance management capabilities of team members are beneficial in identifying team and individual performance.While present construction projects vary in their degrees of complexity, they all still need the competencies of various individuals to be coordinated and effectively managed as a team (Tilley, 2005). Therefore, design management is becoming progressively accepted as being essential to the success of any complex construction project (Newton, 2008). According to Rounce (1998) many of the quality and effectiveness problems faced during the design process are due to ineffective design management. These findings were supported by Tozrtzopouols (2004) who mentioned that inadequate design management contributes considerably to inadequate design process performance. To move toward green building, one of Shafii and Othman (2007) and Knesl et al. (1999) recommendations was concerned with the development of decision-making tools for the construction industry.

Leadership style is one of the various factors that encourage teamwork (Mausberg, 2004). Leaders can be formally selected or can informally appear during group interaction (Keyton and Beck, 2008). According to Morgeson et al. (2010) team leadership is to satisfy the team's requirements and to foster team effectiveness. According to Odusami et al. (2003) Mathieu et al. (2008) leadership has been revealed as a significant factor in project success. Since construction work in general requires team efforts, leadership must have a great influence on construction work performance.

Several empirical research efforts have discovered how the function of team leadership influences team function. For instance, Kane et al. (2002) Morgeson et al. (2010) Klein and Kozlowski (2008) investigated team leaders who perform task functions needed for team performance. They found a positive relationship between leaders and team productivity. The purpose of leadership in the design process is to ensure effective design team performance through leading and influencing how the team works together to utilize the strengths of its constituent parts. Newton (2008) and Girard and Robin (2006) believe that the design team leader should maintain and promote the team through effective leadership and team selection.

\subsubsection{Effective communication and conflicts management}

A number of studies have investigated communication effectiveness. According to Otter and Emmitt (2007), the effectiveness of communication among design team members is highly dependent on the communication acts of the members, their preferred particular communication media and the capabilities of team leaders to facilitate and encourage their team members to communicate as a team effectively. Additionally, Forsyth (2010) mentioned that effective communication between teams is dependent on all of the team members 
willingness, actions and reactions, paying attention and sharing to develop their competencies for effective communication utilization.

Chan and Kumaraswamy (1997), Gorse and Emmitt (2003), Hes (2005) and Emmitt and Gorse (2007) mentioned that the combination of an increasing design process fragmentation, the insatiable requirement for comprehensive information and an increasing client expectation level has lead to greater stress on the necessity and requirement for effective communication.

Conflict resolution is very crucial to team effectiveness .Throughout team interactions, it is occasionally difficult to keep positive interpersonal relationships since individuals have different plans, principles, attitudes and interpersonal communication manners, which can cause interpersonal stress and reduce team effectiveness (Gilley et al., 2010). Moum (2006) and Kirkman et al. (2000) mentioned that a failure of communication among project participants can cause misunderstandings and conflicts that may affect project performance if not realized and resolved at an early stage. competencies require members of the team to be capable to understand and promote desirable conflicts but hinder undesirable conflicts (Stevens and Campion, 1999). Referring to this issue. Bolton and Bolton (2009) suggested that conflicts will take place along the way and quick conflict management is needed to get the team back on track and to keep relationships among the team at a very professional level and to prevent personal conflicts that influence team performance.

\subsubsection{Clarity of roles}

The rising complexity of building projects requires greater emphasis on the collaboration and management of design teams and other project participants (Khaidzir and Anwar, 2007 and Soetanto et al., 2000). The delivery of green performance also requires an increased collaboration among a variety of project stakeholders at the design stage (Knesl, et al., 1999). Rohracher (2001) found that the relationship between design team members through more cooperative collaboration to achieve green building projects.

The delivery of a green performance project requires early formation of the project team the major project team members must be recognized from the beginning of the project, consequently so that the procedures of generating an integrated design solution can begin. Considering green goals, requirements and necessities at the preliminary time will assist with the prompt appointment of related professionals. The roles and responsibilities of design professionals must be clearly described and classified to ensure that the green initiatives that they are responsible for are developed, refined and applied from the beginning of the project. If roles and responsibilities are not assigned, green initiatives might potentially be mistaken or cut out (Danielle, 2007).

\subsection{Green Design Team Attributes}

\subsubsection{Design team knowledge on green building}

Design knowledge is mostly concerned with the knowledge regarding design, (Imre, 2004). Mathieu et al. (2008) concluded that the cognitive ability in teams can influence team's performance. Egbu and IIozor (2007) highlighted that importance of the acquisition of suitable skills, knowledge and capabilities through appropriate education and training. Due to 
increasing technology and complexity, the construction industry now needs greater 'knowledge workers' than in the past, (Baccarini, 1996). The significance of a knowledgeable project team has been pointed out by (Othman et al., 2005).

A lack of previous knowledge of a design team may lead to a significant risk and affect the overall project performance, (Stewart, 2006). Johnson (2005) and Megat (2006) found that the key barriers of applying green building features are team knowledge and understanding of green rating systems. These findings were supported by Karlson et al (2008) who also found that design teams need to be aware regarding the principles of green design requirements and measures. Therefore, more education about the green design process is required. However, Shari et al (2008) argued that the Malaysian building industry players have "insignificant" knowledge on sustainability in general as well as on Green Building Rating Systems (GBRS) in specific. Furthermore, the study argued that the lack of knowledge on the economic benefits of the green approach and implementing GBRS. This observation is echoed by Shafii and Othman (2008) who identified the key barriers to promoting sustainability in Malaysia. For the construction industry to shift green design, Shafii and Othman (2007) and Isabel and Cyril (2007) recommended that education and training must include green development concepts and to make it well known and acknowledged by all people. Providing education and training to building project stakeholders might change green building perceptions as well as provide the knowledge required to integrate green building technology into a project (Sandra, 2005).

To achieve green buildings, design teams should be knowledgeable about environmental issues during their professional training, (Kim, 1998). Lee and Egbu (2006) recommended that the designer should be multi-skilled with several competent knowledge areas in all of the different features of building design. Complemented by management skills and knowledge to meet all of the green design challenges, (Koukkari, et al., 2005 and Danielle, 2007).

Therefore, the design teams are required to be equipped with the knowledge and tools to be capable of interpreting green aspects into design, the increasingly stringent environmental performance objectives of clients and create buildings that meet these new goals (Graham, 2003).

\subsubsection{Design team skills on green building}

A good design team must have the appropriate design skills and ability to interpret the clients' requirements, (Jayasel, 2006). Green design requires a variety of skills and perspectives to demonstrate how final designs will comply with green performance requirements.

Recently, the criteria for selecting design team members has been widen to include their skills on design team process (Feild et al., 2006; Kumaraswamy and Anvuur, 2008). Team building is designed to provide skills and promote high levels of team performance and to help employees increase their levels of interest in and commitment to teamwork (Driskell, et al., 2006; Gilley, et al., 2010). Many factors related to the skills of design teams and team members are proposed for high performance projects. The skills of the team members are found to be a critical factor, (Belassi and Tukel, 1996).

The skills and abilities of team members have a major influence on overall team 
performance (Gatewood et al., 2008). Therefore, the skills and characters of every single team member have to be observed and to be considered because it may affect the final performance output of a team, (Driskell et al., 2006; Mathieu et al., 2008; Psych et al., 2008) Daghfous (2003) and Chow and Ng (2007).

\section{Materials And Methods}

The study is part of Ph.D. research, a triangulation technique was implemented, which combined quantitative and qualitative date collection approaches. The research was performed throughout three main stages, the first stage was a comprehensive literature review validated in a preliminary questionnaire survey. Data collection involving semi-structured interviews was the second stage. The main aim of this stage was to upgrade and refine the research problem and proposed theoretical framework. The last stage involved the final questionnaire survey, in which data was collected for statistical analysis purposes. Prior of this survey preliminary questionnaire was posted. Four research variables were verified.

To investigate performance of design teams during design green buildings practice, in final questionnaire survey, the questionnaire was divided into two parts. The first part requires respondents to provide their personal particulars, whereas, the second part focuses on uncovering the key design team attributes. A survey package consisting of the detailed questionnaire was posted to professionals in various architectural consultancy firms as well as engineering consultancy firms, selected by the lists of architects and engineers provided from their organizations. The population for this study became key design team players for architects and engineers. Only architects registered in PAM and Engineers registered in AECM are selected as the research context. The target population includes architects and Engineers working in design consultancy located in Malaysia. A total of 274survey questionnaire were distributed, 102 valid replies were received, which represents a response rate of $37.1 \%$. WINSTEPS software was used for Rasch Modeling of the Principal Performance Measures to examine data validity and reliability was analyzed. SPSS virsion19, software was used to analyses data collected. The technique of descriptive statistics was used to describe and make sense of the data. The descriptive statistics included the frequency and mean for studied variables.

\subsection{Validity and reliability}

Prior to analysis, functioning of the 5-point Likert scale was examined according to the criteria by Linacre (2006). More than 10 observations are found in each category. Table 1 shows the rating scale category function data for design team attributes suggesting no category disordering. Beside, both the observed average measures and category measure are characterized by criterion of monotonic advance. The Outfit MNSQ values, which are close to infit MNSQ values, for each category are all close to 1.00 and less than 2.00, suggesting that each label was providing measurement information rather than noise in the data. The threshold estimates increase with the category label, indicating that the response categories were used in expected and intended manner. These evidences suggested that the rating scale categories are effectively satisfactory for effective design team variable. 
Table 1. Key reliability and validity parameters of effective design team attributes items

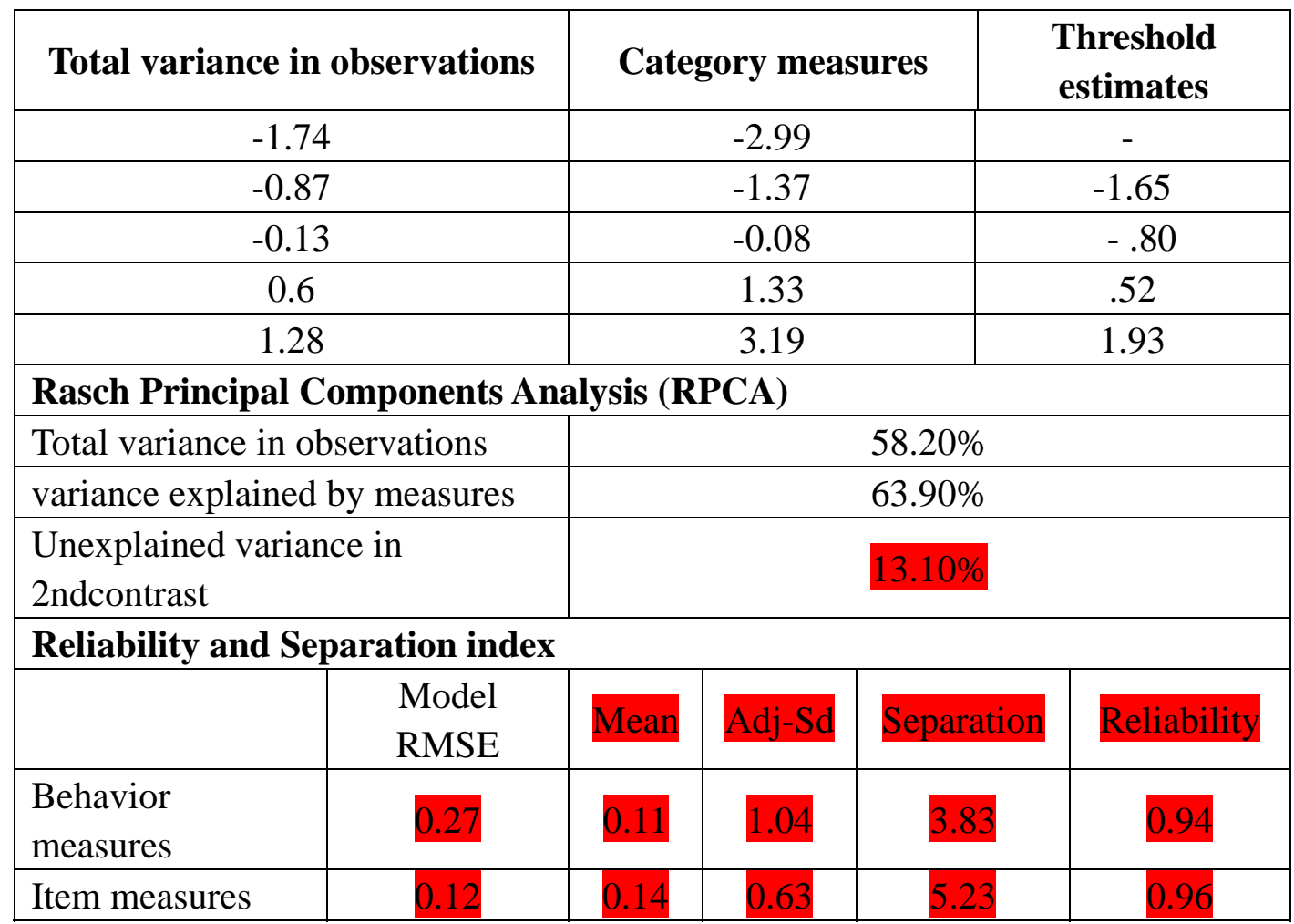

Reliability and Separation Index: As can be seen from Table 2, reliability of all variables item difficulty measure was very high (0.96). This suggested that the ordering of item difficulty was highly replicable with other comparable sample from similar population. The item separation index was very high which are considerably higher than the minimum desired 2.00. The Adj-Sd was at accepted estimate. The item measure RSME measure was 0.12 which considered very well. Taken together, these statistics indicate good separation between items and item measures.

\subsection{Dimensionality test of variables}

For the design team attributes with five-category response model as can be seen in Table 2, all items had acceptable outfit MNSQ statistics between 0.67 and 1.37 the lowest infit was 0.48 whereas the highest was 1.41 suggesting that it was not redundant items with considering high values may represent a lack of homogeneity with other items in the subscale. All items had high to very high PTMEA correlations (0.48-0.76) which exceeded .20 as critical value for the correlation. Positive sign of correlation values identified that the items are systematically correlated in the same direction, measuring the same latent variable calling "Design Team attributes”, therefore, all items had good discrimination.

Table 2: Item statistics: misfit order and item correlations

\begin{tabular}{|c|c|c|c|c|c|c|}
\hline \multirow{2}{*}{ Variables } & \multicolumn{3}{|c|}{ MNSQ } & \multicolumn{2}{c|}{ PTMEA } \\
\cline { 2 - 7 } & \multicolumn{2}{|c|}{ outfit } & \multicolumn{2}{c|}{ infit } & \multicolumn{2}{|c|}{} \\
\hline \multirow{2}{*}{ Clients' qualities } & Lowest & Highest & Lowest & Highest & Lowest & Highest \\
\cline { 2 - 7 } & 0.67 & 1.37 & 0.67 & 1.41 & 0.48 & 0.76 \\
\hline
\end{tabular}




\section{Results}

The quality of the Design Team Attributes were measured. Table 3 shows that, overall, the quality of the Design Team Attributes is moderate, with a mean of 3.32. This confirms the findings in many literatures that buildings in Malaysia generally are not green ( Yusuf et al., 2004, Aziz and Adnan, 2008; Shari et al., 2008). Out of 21variables, only two variables were rated high and interestingly, all the variables are related to the General Attributes. In contrast the bottom seven variables i.e. are all related to Green Attributes.

\subsection{Design team experience}

Since there are 21 design Team Attributes variables measured in this study, it would be lengthy and tedious to explain and discuss on each one of them. However, a pattern on the quality of the design Team Attributes could be established by examining the top three, the middle and the bottom three variables.

The experience of the design teams, with a mean of 3.81 is ranked first. The experience is useful because it can be applied whenever the design teams are facing with recurring problems. Motowidlo and Van Scotter (1994) found that task performance was more highly correlated with experience. For further analysis, a frequency distribution table is produced on this variable. This is shown in Table 4. The table shows that less than 10 percent of the design teams have has low / very low experience in the construction industry. In contrast, about two-third have high / very high experience.

Table 3. The quality of design team attributes during the design process of building projects

\begin{tabular}{|c|l|c|c|c|}
\hline $\begin{array}{c}\text { Attributes } \\
\text { type }\end{array}$ & \multicolumn{1}{|c|}{ Items } & Mean & Rank & Score \\
\hline General & Experience in construction industry & 3.81 & 1 & High \\
\hline General & Leadership Effectiveness & 3.48 & 2 & High \\
\hline General & Communication Effectiveness monitoring & 3.43 & 3 & Moderate \\
\hline General & $\begin{array}{l}\text { Effectiveness of controlling and } \\
\text { design development }\end{array}$ & 4.43 & Moderate \\
\hline General & clarity of roles among design team members & 3.41 & 5 & Moderate \\
\hline General & $\begin{array}{l}\text { Effectiveness of controlling and monitoring to } \\
\text { produce economic design }\end{array}$ & 3.41 & 6 & Moderate \\
\hline General & Effectiveness of managing conflicts & 3.40 & 7 & Moderate \\
\hline General & Experience in similar type and size & 3.36 & 8 & Moderate \\
\hline General & Decision making effectiveness & 3.36 & 9 & Moderate \\
\hline Green & Commitment level of the architect & 3.35 & 10 & Moderate \\
\hline Green & Commitment level of M \& E engineers & 3.26 & 11 & Moderate \\
\hline Green & Interest on green design assignment & 3.16 & 12 & Moderate \\
\hline Green & Skills of Interpreting client needs & 3.16 & 13 & Moderate \\
\hline Green & Skills of using green related programs & 2.13 & 14 & Moderate \\
\hline Green & Knowledge relevant to green design & 15 & Moderate \\
\hline Green & Attention to green design and construction details & 2.86 & 16 & Moderate \\
\hline Green & offering suggestions to improve green design & 2.84 & 17 & Moderate \\
\hline
\end{tabular}




\begin{tabular}{|l|l|l|l|l|}
\hline Green & Speed in producing green design drawings & 2.80 & 18 & Moderate \\
\hline Green & Ability in overcoming green design difficulties & 2.76 & 19 & Moderate \\
\hline Green & Knowledge of green design assessment tools & 2.75 & 20 & Moderate \\
\hline Green & Commitment of QS to select green materials & 2.72 & 21 & Moderate \\
\hline & Average & 3.32 & & Moderate \\
\hline
\end{tabular}

Key: 1-1.8 very low, 1.9-2.6 low, 2.7-3.4 moderate, 3.5-4.2 high, 4.3-5 very high

Table 4: Influence of experience in construction

\begin{tabular}{|c|c|c|}
\hline Experience level & $\begin{array}{c}\text { Frequency } \\
(\mathbf{N = 1 0 2})\end{array}$ & Percentage \\
\hline Very low & 1 & 1 \\
\hline low & 8 & 7.8 \\
\hline Moderate & 26 & 25.5 \\
\hline High & 41 & 40.2 \\
\hline Very high & 26 & 25.5 \\
\hline Mean & & 3.81 \\
\hline
\end{tabular}

\subsection{Leadership effectiveness in design process}

Leadership Effectiveness in the Design Process is ranked second, with a mean of 3.48, which is categorized as high quality. The function of team leadership consists of elements that become significant through the action phase which comprises monitoring the performance environment of the team, boundaries management between the team and organizational environment, encouragement for continual improvement, more involvement in performing tasks, problem solving, acquiring resources and encouragement to act autonomously (Marks et al., 2001). It is crucial to identify the role and responsibilities of design process leaders to achieve an effective design process (Newton, 2008). Control relationship between the project leader and team members is essential to effective performance. (Henderson \& Soonchul, 1989). Team monitoring is a critical function to team leadership because it provides significant conveyance of many of the other relationship tasks, such as procedures and team performance. (Morgeson et al., 2010).

Therefore, design Team Leadership in the perspective of Design Management intends to ensure effective design team performance through leading and influencing how the team works together to utilize the strengths of its constituent parts.

For more detail analysis on the quality of Leadership Effectiveness during green design process, Table 5 is produced. The result shows that the Leadership Effectiveness of the design teams is generally high (mean 3.5). Only 15.7 percent of the design teams have low/very low Leadership Effectiveness, while more than half (54.9\%) of the design teams have high / very high Leadership Effectiveness during design process. 
Table 5. Leadership effectiveness during green design process

\begin{tabular}{|c|c|c|}
\hline Leadership effectiveness level & Frequency & Percentage \\
\hline Very low & 1 & 1 \\
\hline low & 15 & 14.7 \\
\hline Moderate & 30 & 29.4 \\
\hline High & 46 & 45.1 \\
\hline Very high & 10 & 9.8 \\
\hline Mean & & 3.48 \\
\hline
\end{tabular}

Key: 1-1.8 very low;1.9 -2.6 Low; 2.7 -3.4 moderate; 3.5-4.2 high;4.2-5.0 very high

\subsection{Communication effectiveness during design process}

The Communication Effectiveness in the design process is ranked third, with a mean value of 3.43, which is categorized as moderate. Considering that the design team members are varied in understanding, approach, abilities, adoption and preference level of the communication tools available (Chan \& Kumaraswamy, 1997 ; Gorse \& Emmitt, 2003) it is important for the communication within the design team to be effective. Thus, to be only moderately effective is not very satisfactory. Further analysis, provided by Table 6, shows that almost half (49.0\%) of the design teams have high / very high Communication Effectiveness.

Table 6. Communication effectiveness level in design process

\begin{tabular}{|c|c|c|}
\hline Communication effectiveness level & Frequency (N=102) & Percentage \\
\hline Very low & 0 & 0 \\
\hline Low & 11 & 10.8 \\
\hline Moderate & 41 & 40.2 \\
\hline High & 45 & 44.1 \\
\hline Very high & 5 & 4.9 \\
\hline Mean & & 3.43 \\
\hline
\end{tabular}

Key:1-1.8 very low;1.9-2.6 Low; 2.7 -3.4 moderate; 3.5-4.2 high;4.2-5.0 very high

\subsection{Commitment of design team members to green}

The level of architect, $\mathrm{M}$ and $\mathrm{E}$ engineers and QS commitment was investigated. The result implies that the commitment level of architects and $\mathrm{M}$ and $\mathrm{E}$ engineers on design green buildings was generally at moderate level with mean 3.35 and 3.26 respectively. Whereas the commitment level of quantity surveyors was at lowest (2.76). Low commitment level quantity surveyor commitment level could be resulted because the quantity surveyor focus on reducing costs rather than implementing green features.

\subsection{Knowledge on design green buildings}

The degree of knowledge of design team on design green buildings was investigated. The result suggests that the knowledge level of design team on green buildings was generally moderate $($ mean $=2.86$ ). The respondents were asked about design team knowledge on design green design assessment tools. As Table 7 shows more than one third (38.3\%) of the design team members were had 'very low' and 'low' knowledge level on design green design 
assessment tools. Followed by $44.1 \%$ of the design teams were moderately knowledgeable on green design assessment tools. Only $17.7 \%$ were high and very high knowledgeable, on the other hand.

Table 7. Level of DT knowledge on DGB assessment tools

\begin{tabular}{|l|c|c|}
\hline \multicolumn{1}{|c|}{ Knowledge level } & Frequency (N=102) & Percentage \\
\hline Very low & 6 & 5.9 \\
\hline Low & 33 & 32.4 \\
\hline Moderate & 45 & 44.1 \\
\hline High & 16 & 15.7 \\
\hline Very high & 2 & 2 \\
\hline Mean & & 2.75 \\
\hline
\end{tabular}

Key:1-1.8 very low1.9-2.6 Low;2.7 -3.4 moderate; 3.5-4.2 high;4.2-5.0 very high

\subsection{Design Team consciousness on green design}

Ability in overcoming green design difficulties was used as one of four measures to identify level of design team consciousness on design green buildings. The ability level of overcoming green design difficulties was investigated. The result reveals that the Ability in overcoming green design difficulties of design team members on design green buildings was generally at lowest three design team attributes with moderated level (2.76).

As Table 8 shows, while $22.6 \%$ of respondents were agreed the ability level of overcoming green design difficulties was 'high' and 'very high', 32.4\% of respondents agreed the ability level was 'very low' and 'low'. Almost half (45.1\%) of respondents agreed the ability level of overcoming green design difficulties were moderate.

Table 8. Ability in overcoming green design difficulties

\begin{tabular}{|c|c|c|}
\hline $\begin{array}{c}\text { Ability of overcoming green } \\
\text { design difficulties }\end{array}$ & Frequency & Percentage \\
\hline Very low & 8 & 7.8 \\
\hline low & 28 & 27.5 \\
\hline Moderate & 49 & 48 \\
\hline High & 14 & 13.7 \\
\hline Very high & 3 & 2.9 \\
\hline Total & 102 & 100 \\
\hline Mean & & 2.76 \\
\hline
\end{tabular}

Key: 1-1.8 very low;1.9 -2.6 Low; 2.7 -3.4 moderate; 3.5-4.2 high;4.2-5.0 very high

\section{Discussion}

The result implies that the design teams have the attributes that are important and sufficient to produce conventional designs of building projects, but they are weak in design related attributes such as green knowledge, conscientiousness on green and commitment to green that are required to produce green designs. Hence, it could be proposed that this is the main reason why the green design performance of buildings in Malaysia is only at moderate level. 
Drawing from the result it could be argued that having high / very Experience in the Construction Industry has a limited impact on the Green Design Performance. If the experience is not related, than the Experience could be used to improve the Green Design Performance.

Since the Effectiveness of Leadership is so important in the design process, it implies that lack of it will greatly affect the Green Design Performance. Therefore, the design teams must have a member who is trained as a leader. Normally, the architects take this role. However, the architects training normally put more emphasis on designs rather than on leadership.

The results imply that effectiveness in the design process is not a major problem in the design process, probably due to the fact that it has been a general practice in Malaysia that the design teams have regular meetings during the design process.

The top three attributes that are related experience, leadership and communication are the attributes that mainly concern with the needs for design team members to work as team. These are the attributes that are required for all types of design, and not dealing with specific requirements, such as green design.

Interestingly, commitment to green and commitment to finance green design attributes are the top two of Green Attributes. However, it has been pointed earlier, that the design team performance in the Green Attributes is lower than the General Attributes. Even though the level of commitments of Architects, M\&E Engineers scored relatively higher than all other Green Attributes, but they still fall under moderate category. Hence, it could be concluded that the quality of the Green Attributes of the design teams is far from satisfactory. But the quality of Green Attributes has a direct influence on the Green Design Performance.

The result indicates that commitments of the design team members will help to produce building designs with green features. The commitment level of design team members toward green design is related to client commitment and also related to budgeting and time frame allocated by the client. The result confirmed findings from Hes (2005) who found that most designers agree that they would enhance their utilization of green design solutions if green design approaches were a corporate mission.

The entire bottom three of the Design Team Attributes i.e., the Ability in Overcoming Green Design Difficulties, Knowledge of Green Design Assessment Tools and the Commitment of Quantity Surveyors to select green materials product are related to Green Attributes. This is not entirely surprising. When this study was conducted, the green building concept was rather new. Hence, it would be difficult for the design team overcome difficulties relating to green design. Furthermore, the GBI was only introduced in 2009, at about the same time this study was conducted. Many designers were still not familiar with the criteria, the procedure and the marking scheme of the GBI.

The result implies that green design is more complex and required additional time during a design process to enable design team to overcome the difficulties that arise during design process. Therefore, design team confronting challenges in delivering green design such as speed of design process and statutory approval. In addition, green design required implementing green building rating assessment tools such as GBI, this lead to additional 
procedures during the design process and need adequate coordination from design team leader and participation.

The result indicates that design teams are not fully occupied by assessment rating tools to apply green design aspects effectively. The result confirmed findings from Megat (2006) who highlighted the that due to the lack of sufficient knowledge about design and construction of green buildings, design teams feel that designing and constructing green building projects is complex and they are struggling to implement environmental design criteria and other green design requirements. further more the result supported Shari, et al.(2008), findings in which they discovered that the Malaysian building industry players have "insignificant" knowledge on sustainability in general as well as on green building rating systems in specific.

The Commitment Level of Quantity Surveyors was at lowest, with a mean value at 2.76. This is expected. From the Preliminary Questionnaire Survey, it was found that the involvement of quantity surveyors in green design was the lowest among the participants investigated. This is partly due to the fact that the quantity surveyors are more concerned about costs. Incorporating green features might increase the cost. However, it could be argued that if the clients are committed to green design, the quantity surveyors will also be committed.

\section{Conclusion}

It can be concluded that the performance of design teams of building projects was at moderate level. In particular, while, two over nine variables measuring performance of design team general attributes were at high level, all the twelve variables measuring performance of design team green attributes was at moderate level. The commitment of the architects on green design was at the highest level and the commitment of quantity surveyor was at the lowest level among green design team attributes measured.

\section{References}

Ali, A.S. \& I. Rahmat. (2008). Involvement of key design participants in refurbishment design process. Facilities, 26: 389-400. DOI:10.1108/02632770810885742

ALwaera, H. \& D.J.C. Croomeb. (2010). Key performance indicators (KPIs) and priority setting in using the multi-attribute approach for assessing sustainable intelligent buildings. Build. Environ., 45: 799-807.

Anita, M. (2006) ). A Framework for exploring the ICT impact on the architectural design process. ITcon, 11: 409-425.

Asad, S. \& M.M.A. Khalfan. (2007). integration of emirates. J. Eng. Res., 12: 11-21.

Baars, P. \& M.A. Gerarde. (2006). Design teams and Personality Effects of team composation on process and effectiveness Eindhoven: Techinchsine University Eindhoven.ISBN: 90-386$0653-2$

Baccarini, D. (1996). The concept of project complexity--a review. Int. J. Project Manag., 14: 201-204.http://dx.doi.org/10.1016/0263-7863(95)00093-3

Belassi, W. \& O.I. Tukel. (1996). A new framework for determining critical success/failure 
factors in projects. Int. J. Project Manag., 14: 141-151.

Bolton, R. \& D.G. Bolton. (2009). People Styles at Work: Making Bad Relationships Good And Good Relationships Better 2nd Edn. New York, NY: AMACOM

Bradly, T.J. (2005). Barriers to certification for LEED registered projects. Colorado State University, Colorado

Carpenter, M.A. (2002). The implications of strategy and social context for the relationship between top management team heterogeneity and firm performance. Strategic Manag. J., 23: 275-284.http://dx.doi.org/10.1002/smj.226

Chan, D.W.M. \& M.M. Kumaraswamy. (1997). A comparative study of causes of time overruns in Hong Kong construction projects. Int. J. Project Manag., 15: 55-63.

Chi, Y.L. \& C.Y. Chen. (2009). Project teaming: Knowledge-intensive design for composing team members. Expert Syst. Appl., 36: 9479-9487. http://dx.doi.org/10.1016/j.eswa.2008.12.015

Chow, L.K. \& S.T. Ng. (2007). Expectation of performance levels pertinent to consultant performance evaluation. Int. J. Project Manag., 25: 90-103. ISSN: 0263-7863

Cohen, S.G. \& D.E. Bailey. (1997). What makes teams work: Group effectiveness research from the shop floor to the executive suite. J. Manag., 23: 239-290. Http://dx.doi.org/10.1016/s0149-2063(97)90034-9

Daghfous, A. (2003). How to make knowledge management a firm's core capability. J. Knowledge Manag. Practice.

Danielle, M. (2007). Design and sustainable commercial buildings. Retrieved from http://www.yourbuilding.org/Article/NewsDetail.aspx?p=83 andid=1571

Driskell, J.E. \& G.F. Goodwin et al. (2006). What makes a good team player? personality and team effectiveness. group dynamics: Theory, Res. Practice, 10: 249-271. http://dx.doi.org/10.1037/1089-2699.10.4.249

Egbu, C.O. \& D. Ilozor. (2007). Construction clients and industry innovations: Understanding of their roles and impact Paper presented at the CIB World Building congress.

Emmitt, S. and C.A. Gorse. (2007). Communication in construction teams. Taylor and Francis.ISBN: 0415366194.

Feild, H.S. \& W.F. Giles et al. (2006). Becoming team players: Team members' mastery of teamwork knowledge as a predictor of team task proficiency and observed teamwork $\begin{array}{lllll}\text { effectiveness. } & \text { J. } & \text { Applied } & \text { Psychol., } & \text { 91: }\end{array}$ http://dx.doi.org/10.1037/0021-9010.91.2.467

Forsyth, D.R. (2010). Group Dynamics, Forth Edition. Belmont, USA: Wadsworth, Cengage Learning.ISBN: 13: 978-0-495-59952-4 
Gatewood, R.D. \& H.S. Feild et al. (2008). Human Resource Selection, Sixth Edition. Natorp Boulevard, USA: Thomson South-Western. ISBN:13: 978-0-324-20728-6

Gilley, J.J.W. \& A.M. Waite et al. (2010). Integrated theoretical model for building effective teams. Advances Developing Human Res., 7-28.http://dx.doi.org/10.1177/1523422310365309

Girard, P. \& V. Robin. (2006). Analysis of collaboration for project design management. Comp. Ind., 57: 817-826.URL: www.elsevier.com/locate/compind

Gorse, C. \& S. Emmitt. (2003). Investigating interpersonal communication during construction progress meetings:challanges and oportunities. Eng., Constru. Architectural Manag., 10: 234-244. http://dx.doi.org/10.1108/09699980310489942

Graham, P. (2003). The Role Of Environmental Performance Assessment In Australian Building Design. The Future of Sustainable Construction(Special Issue article ). ISBN 1-886431-09-4.

Hes, D. (2005). Facilitating 'Green' building:turning observation into practice. RMIT University.

Hoare, J.D. (2006). The Use Of The Charrette To Support Collaborative Design And Planning For The Built Environment: Selling The Benefits. Cranfield University.

Hoegl, M. \& H.G. Gemuenden. (2001). Teamwork quality and the success of innovative projects: A theoretical concept and empirical evidence. Organization Sci., 12: 435-449.http://dx.doi.org/10.1287/orsc.12.4.435.10635

Humphrey, S.E. \& F.P. Morgeson et al. (2009). Developing a theory of the strategic core of teams: A role composition model of team performance. J. Applied Psychol., 94: 48-61. http://dx.doi.org/10.1037/a0012997

Hyatt, D.E. \& T.M. Ruddy. (1997). An examination of the relationship between work group characteristics and performance: Once more into the breech. Personnel Psychol., 50: 553-585. http://dx.doi.org/10.1111/j.1744-6570.1997.tb00703.x

Imre, H. (2004). A treatise on order in engineering design research. Res. Eng. Design, 15: 155-181. DOI 10.1007/s00163-004-0052-X

Isabel, M. \& S. Cyril. (2007). Transforming existing buildings: The Green Challenge 978: 325-9. ISBN: 978-1-84219-325-9

Jackson, S.E. \& A. Joshi et al. (2003). Recent research on team and organizational diversity: SWOT analysis and implications. J. Manag., 29: 801-830. http://dx.doi.org/10.1016/S0149-2063(03)00080-1.

Jayasel, R.P. (2006). Development Of Civil And Structural Consultant's Performance Evaluation. Universiti Teknologi Malaysia, Jahor. 
Jordan, M.H. \& A.A. Armenakis. (2002). The relationship of group process variables and team performance: A team-level analysis in a field setting. Small Group Res., 33:121-150. DOI : $10.1177 / 104649640203300104$

Kane, T.D. \& S.J. Zaccaro et al. (2002). An examination of the leader's regulation of groups. Small Group Res., 33: 65-120. http://dx.doi.org/10.1177/104649640203300103

Karlson, C.H. \& R. Stephens et al. (2008). A primer series for sustainable design charrettes. 1. Harnessing the potential of design teams to achieve sustainable design outcomes: Chimera

Katsanis, L.P. \& J.P.G. Laurin et al. (1996). How should product managers' job performance be evaluated in emerging product management systems. J. Product Brand Manag., 5: 5-23.

Kerr, P. (2008. High Performance Buildings: The Process of Delivery for Universities and Colleges.

Keyton, J. \& S.J. Beck. (2008). Team attributes, processes and values: A pedagogical $\begin{array}{lllll}\text { framework. } & \text { Bus. } & \text { Commun. } & \text { Quarterly, } & \text { 41: }\end{array}$ http://dx.doi.org/10.1177/1080569908325863

Khaidzir, M. and K. Anwar. (2007). Shaping the future of the architectural proffession. FAB J., 1-6.

Kim, J.J. (1998). Introduction to Sustainable Design, Sustainable Architecture Module. Michigan: National Pollution Prevention Center for Higher Education.

Kirkman, B.L. \& R.G. Jones et al. (2000). Why do employees resist teams? examining the "resistance barrier" to work team effectiveness. Int. J. Conflict Manag., 11: 174-92.http://dx.doi.org/10.1108/eb022836

Klein, K.J. and S.W.J. Kozlowski. (2008). Leadership: Enhancing Team Adaptability in Dynamic Settings (No. 611102.B74F ). Virginia, U.S.A: United States Army Research Institute for the Behavioral and Social Sciences.http://dx.doi.org/10.1177/1046496408328821

Knesl, J. \& C. Latman et al. (1999. High Performance Building Guidelines.

Koukkari, H. and L. Bragança et al. (2005). Sustainable design principles in construction sector. Paper presented at the International Conference Sustainable Construction: Action For Sustainability In The Mediterranean. Retrieved from http://hdl.handle.net/1822/5071

Kozlowski, S.W.J. \& D.R. Ilgen. (2006). Enhancing the effectiveness of work groups and teams. Association Psychol. Sci., 7: 3.

Krishnan, M.S. (1998). The role of team factors in software cost and quality An empirical analysis. Infor. Technol. People 11: 20-35.

Kumaraswamy, M.M. and A.M. Anvuur. (2008). Selecting sustainable teams for PPP projects. Build. Environ., 43: 999-1009.ISSN: 0360-1323

Lee, C.C. \& C.O. Egbu, (2006). 7th and 8th September 2006). The Development of a Methodology to Match the Client's Project Requirements with the Knowledge of the Project 


\section{Macrothink}

Environmental Management and Sustainable Development

ISSN 2164-7682

2012, Vol. 1, No. 1

Team in Refurbishment Projects. Paper presented at the The Annual Research Conference Of The Royal Institution Of Chartered Surveyors, University College London.ISBN: 978-1-84219-307-4

LePine, J.A. (2003). Team adaptation and postchange performance: Effects of team composition in terms of members' cognitive ability and personality. J. Applied Psychol., 88: 27-39.ISSN: 0021-9010

Loughry, M.L. \& M.W. Ohland et al. (2005). Development of a Theory-Based Assessment; Development of a Theory-Based Assessment of Team Member Effectiveness (No. 0243254): Clemson University

Lukumon, O.O. \& K.W. Thamb. (2007). Clients' assessment of architects' performance in building delivery process: Evidence from Nigeria. Build. Environ., 42: 2090-2099.http://dx.doi.org/10.1016/j.buildenv.2005.06.030

Mac Cormack, A. \& R. Verganti et al. (2001). Developing products on "internet time. The anatomy of a flexible development process. Manag. Sci., 47: 133-150.ISSN: 1526-5501

Mathieu, J. \& M.T. Maynard et al. (2008). Team effectiveness 1997-2007: A review of recent advancements and a glimpse into the future. J. Manag., I: 34-410.http://dx.doi.org/10.1177/0149206308316061

Mausberg, J. (2004). Building a Better Team. ICEIMT, pp: 173-184.

Megat, A.A. (2006). The Limitations and Opportunities to Implement Environmental Management System in Malaysia. J. Alam Bina.

Mohamed, S.L.C. (2003). Personality heterogeneity in teams: Which differences make a difference for team performance. Small Group Res., 34: 651-677.http://dx.doi.org/10.1177/1046496403257228

Mohammed, S. \& E. Ringseis. (2001). Cognitive diversity and consensus in group decision making: The role of inputs, processes and outcomes. Organizational Behavior Human Decision Processes, 85: 310-335. http://dx.doi.org/10.1006/obhd.2000.2943

Morgeson, F.P. and D.S. DeRue et al. (2010). Leadership in teams: A functional approach to understanding leadership structures and processes. J. Manage., I: 5-19.http://dx.doi.org/10.1177/0149206309347376

Newton, A. (2008). What is effective Design Management? Adept Management Ltd.

Odusami, K.T. and R.R.O. Iyagba et al. (2003). The relationship between project leadership, team composition \& construction project performance in Nigeria. Int. J. Project Manag., 21: 519-527.

Othman., A.A.E. \& T.M. Hassan et al. (2005). Analysis of factors that drive brief development in construction. Engineering. Construction Architectural Manag., 12: 69-87.http://dx.doi.org/10.1108/09699980510576907 
Otter, A.d. \& S. Emmitt. (2007). Exploring effectiveness of team communication-balancing synchronous and asynchronous communication in design teams. Eng. Construction Architectural Manag., 14: 408-419.http://dx.doi.org/10.1108/09699980710780728

Peeters, M.A.G. \& T.H.F.J.M. Van et al. (2006). Personality and team performance: A Meta-Analysisy. Eur. J. Personality, 20: 377-396.http://dx.doi.org/10.1002/per.588

Psych, D. and M. Pioro et al. (2008). Team Engineering for High-Risk Environments. Paper presented at the 12th International Workshop on Team Working (IWOT)

Rahmat, I. \& A.S. Ali. (2010). The involvement of the key participants in the production of project plans and the planning performance of refurbishment projects. J. Build. Appraisal, 5: 273-288.

Rajagopal, and R. Ananya. (2006). Trust and Cross-Cultural Dissimilarities in Corporate Environment. SSRN eLibrary

Rohracher, H. (2001). Managing the technological transition to sustainable construction of buildings: A socio-technical perspective. Technology Analysis Strategic Manag., 13: 137-150.http://dx.doi.org/10.1080/09537320120040491

Rounce, G. (1998). Quality, waste and cost considerations in architectural building design $\begin{array}{lllll}\text { management. Int. } \quad \text { J. } & \text { Project } & \text { Manag., } & 16: & \text { 123-127. }\end{array}$ http://dx.doi.org/10.1016/S0263-7863(97)00042-2

Sahil, N. (2008). Nonvation Agreement In Design And Build Contracts Univesiti Teknologi Malaysia Shah Alam

Salas, E. \& C. Prince et al. (1995). Situation awareness in team performance: Implications Measur. Training. Human Factors, 37: 123-136.

Sandra, G. (2005). The Massachusetts Story: The Current State of Sustainable Design at Massachusetts State Agencies and Authorities. Boston. The Massachusetts Sustainable Design Roundtable.

Shafii, F. \& M.Z. Othman. (2007). Sustainable building in the malaysian context. Paper presented at the The International Conference on Sustainable Building Asia, Seoul, Korea

Shafii, F. \& M.Z. Othman. (2008). Green for Better Buildings.Retrieved from http://web.utm.my/skpost

Shari, Z. and J.M.F. Zaky et al. (2008. The potential of sustainable building rating system in the malaysian building industry. Int. J. Sustainable Tropical Design Res. Practice, 3: 3-14.

Shirazi, A. \& S. Mortazavi. (2006). Effective Management Performance A Competency-Based Perspective. ISSN: 1823-723.

Shirazi, A. \& S. Mortazavi. (2009). Effective management performance-a competency-based perspective. Int. Rev. Busi. Res. Papers, 5: 1-10.

Soetanto, R. \& D.G. Proverbs et al. (2000). The performance of the project coalition in the 
UK construction industry: A conceptual optimisation model. Dimensi Teknik Sipil, 2: 104-110. ISSN: 1410-9530.

Sonnentag, S. \& M. Frese. (2002). Psychological management of individual performance chapter one- performance concepts and performance theory (Sonnentag, S. (Edn.). West Sussex, UK: John Wiley and Sons, Ltd. ISBN: 0471877263C1

Stevens, M.J. \& M.A. Campion. (1999). Staffing work teams: Development and validation of a selection test for teamwork settings. J. Manag., 25: 207-228.http://dx.doi.org/10.1177/014920639902500205

Stewart, G.L. (2006). A meta-analytic review of relationships between team design features and team performance. J. Manag., 32: 29.http://dx.doi.org/10.1177/0149206305277792.

Strubler, D.C. \& K.M. York. ( 2007). An exploratory study of the team characteristics model using organizational teams. Small Group Res., 38: 670-695.http://dx.doi.org/10.1177/1046496407304338

Tilley, P.A. (2005). Lean Design Management-A New Paradigm for Managing the Design and Documentation Process to Improve Quality Paper presented at the Proceedings IGLC, Sydney, Australia.

Tozrtzopouols, P. (2004). The design and implementation of product development process models in construction companies University of Salford, Salford, UK.

Tucker, S.N. \& M.D. Ambrose et al. (2003). Integrating eco-efficiency assessment of commercial buildings into the design process: LCADesign. Paper presented at the CIB 2003 International Conference on Smart and Sustainable Built Environment.

Vardi, Y. \& E. Weitz. (2004). Misbehavieor in organizations: Theory, Research and Management: Lawrence Erlbaum Associates, Publishers, Mahwah, New Jersey, London. ISBN: 0-8058-4332-9.

Yean, Y.L. (2002). Model for predicting performance of architects and engineers. J. Construction Eng. Manag. 128: 446-455.http://dx.doi.org/10.1061/(ASCE)0733-9364(2002)128:5(446)

\section{Copyright Disclaimer}

Copyright reserved by the author(s).

This article is an open-access article distributed under the terms and conditions of the Creative Commons Attribution license (http://creativecommons.org/licenses/by/3.0/). 